\title{
Universiteit
}

Leiden

The Netherlands

\section{A Chinese relative}

Sybesma, R.P.E.; Cheng, L.L.; Broekhuis, H.; Corver, N.; Huijbregts, R.; Kleinhenz, U.; Koster, J.

\section{Citation}

Sybesma, R. P. E., \& Cheng, L. L. (2006). A Chinese relative. In H. Broekhuis, N. Corver, R. Huijbregts, U. Kleinhenz, \& J. Koster (Eds.), Studies in Generative Grammar (pp. 69-76). Berlin: De Gruyter Mouton. doi:10.1515/9783110892994.69

Version: $\quad$ Publisher's Version

License:

Licensed under Article 25fa Copyright Act/Law (Amendment Taverne)

Downloaded from: $\quad$ https://hdl.handle.net/1887/3247494

Note: To cite this publication please use the final published version (if applicable). 


\section{A Chinese relative}

\section{Lisa Lai-Shen Cheng and Rint Sybesma}

\section{Background ${ }^{1}$}

Van Riemsdijk (2003) analyses Züritüïtsch relative clauses with wo which look like gapless relatives in certain respects, see (1), as involving a syntactic variable bound by an expletive locative operator in SpecCP.

(1) a. s mäitli wo öpper wo mit ere i's kino gaat

a girl wo someone wo with her in the cinema goes

zimli mues spine

(Van Riemsdijk (9))

quite must be.crazy

'a girl that someone who goes to the movies with her must be pretty crazy'

b. Es äuto wo d stoosstange fëëlt ghöört nöd uf $d$ straass a car wo the fender misses belongs not on the street 'A car that has no fender on it does not belong on the street'

(Van Riemsdijk (12a))

He then wonders whether studies on supposedly gapless relatives in such languages as Japanese and Korean need to be reconsidered. In this squib we heed his call and investigate supposedly gapless relatives in Mandarin Chinese. We concentrate on the ones in (2), which seem pretty 'gapless', even more so than the ones in (3).

(2) a. [REL tā chàng ge $\bar{e}$ de $]$ shēngyīn he sing song DE voice 'the voice that he has while singing'

b. [REL tā shuìjiào de] zīshì

he sleep DE posture

'the posture that he has while sleeping'

\footnotetext{
${ }^{1}$ We thank Boya Li for discussing the Mandarin examples with us.
} 
(3) a. [ReL tā xiū chē de] chēkù

he fix car DE garage

'the garage where he fixes his car'

b. RRLL $_{\text {tā }}$ xiū chē de] yuányīn

he fix car DE reason

'the reason why he fixed his car'

Like all other prenominal modifiers, the relatives in these examples are marked by clause-final $d e$, which has been called by many different names, e.g. 'modification marker' (Cheng 1997), 'subordinator' (Paul 2003) or 'linker' (Den Dikken and Singhapreecha 2004). The reason why the examples in (2) can be considered more gapless than the ones in (3) is that the head nouns in the latter can be analysed to relate to an adjunct position in the relative clause (in the case of (3a) a locative, in that of ( $3 b$ ) a reason adjunct) and such a position does not seem readily available in the examples in (2). However, Ning (1993) aligns cases in (2) to the ones in (3) by proposing that in (2), the head noun and the relative clause are involved in a result relation, which is derived from a VP-adjunct expressing the notion of 'obtain'. This way, both types of 'gapless' relatives are not gapless at all as both have a non-overt adjunct position, bound by an empty operator in the CP domain.

The analysis Van Riemsdijk (2003) proposes for Züritüütsch examples such as (1) above is similar to Ning's analysis for the Mandarin Chinese cases in (2) and (3) in assuming that an eventually non-overt adjunct plays a role in the syntax of these cases, but is very different in all other respects. In Van Riemsdijk's analysis, the adjunct, referred to as 'expletive adjunct', is the same in all cases. The function of this free adjunct is to mediate between the head of the relative clause and the more deeply embedded semantic content of the relative clause itself, thus expressing the 'aboutness' semantics which is so typical of 'gapless' relatives. Syntactically, the expletive adjunct, which is a locative adjunct for language specific reasons, $w h$-moves to SpecCP. It gets no PF-realization for phonological reasons; it is not base-generated as such. ${ }^{2}$

In what follows we investigate (what we will from now on refer to as) 'aboutness' relatives in Mandarin.

\footnotetext{
${ }^{2}$ Specifically, the moved locative adjunct would be wo. The wo's we see in (1) are in $\mathrm{C}^{0}$. With one wo in SpecCP and one in the head, we would get wo wo which comes out as wo.
} 


\section{Lesser-known features}

Aside from the issue of the gap, the literature on aboutness relatives in Mandarin, does not pay much attention to the other properties of such phrases. For instance, there is not much discussion on the fact that there actually are constraints on the formation of aboutness relatives that go beyond the matter of world knowledge (that is, go beyond the question whether the relative clause can in any possible way be construed as being 'about' the head noun). However, there are a number of constraints, two of which we discuss here.

\subsection{Activity vs. state}

All the Mandarin examples of aboutness relatives provided in the literature involve some kind of activity. That is, the verbs in the relatives are activity

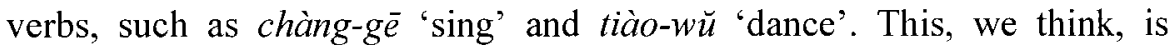
actually not an accidence, as non-activity verbs in gapless relatives yield clear-cut degrading results.

(4) a. Zhāngsān hĕn gāo

Zhangsan very tall

'Zhangsan is very tall.'

b. "? [tā hěn gāo de] yĭngzi

he very tall $D E$ shadow

Intended: 'the shadow reflecting that he is tall'

c. Lisì hěn cōngmíng

Lisi very intelligent

'Lisi is very intelligent.'

d. ?? [tā hěn cōngmíng de] táidu he very intelligent $\mathrm{DE}$ attitude

Intended: 'the attitude that he is intelligent'

Adjectives in Chinese can be used as predicates, but they are not allowed in gapless relatives, as shown in (4b) and (4d). The contrast between (5a)-(6a) and $(5 b)-(6 b)$ is very telling:

(5) a. ?? wŏ xĭhuān [[tā hěn gāoxìng de] xiàoróng] I like he very happy DE smile 'I like the smile which reflects that he is happy.'

b. wǒ xĭhuān [[tāā gāoxìng qî-lái de] xiàoróng]

I like he happy INCHO DE smile

'I like the smile which reflects that he turns happy.' 
(6) a. ??wŏ hěn shúxī [[tā hěn jŭnzhāng de] yàngzi] I very familiar he very nervous DE look 'I am very familiar with how he looks when he is nervous.'

b. wǒ hěn shúxī [[tā jünzhāng qŭ-lái de] yàngzi $]$ I very familiar he nervous INCHO DE look 'I am very familiar with how he looks when he gets nervous.'

In (5a) and (6a), the relative clause contains a stative/adjectival predicate, and the sentence is ungrammatical. However, when the adjective is combined with qü-lái, an inchoative marker normally attached to activities, the adjective gets an activity reading and the sentences $((5 b)$ and (6b)) become grammatical. These examples illustrate thus a constraint of the verb types in aboutness relatives.

\subsection{Generic activity reading}

In addition to the fact that the predicate in an aboutness relative must denote an activity, we note that the activity must be able to be interpreted generically. That is, it cannot be temporally restricted. Consider the contrast between $(7 a, b)$ and $(7 c)$.

(7) a. tā chàng-guo de nèi-shǒu gē

he sing-EXP DE that-CL song

'the song that he sang before'

b. chàng-guo nèi-shǒu gē de gēshǒu sing-EXP that-CL song DE singer

'the singer who sang that song before'

c. *tā chàng-guo (nèi-shǒu) gē de shēngyīn

he sing-EXP that-CL song DE voice

Intended: 'the voice that he had when he sang (the) song before'

Although the experiential aspect can be used in regular relatives $(7 \mathrm{a}, \mathrm{b})$, it cannot be used in gapless/aboutness relatives (7c). Nor can we use other aspectual markers such as $l e$ 'perfective'. Aboutness relatives are best if there is absolutely no aspectual marking, and no specific markings on the object nominal as well. In other words, an aboutness relative is interpreted as a generic activity/event. In the case of (2a), it is the activity of singing that is connected to the head noun, and in ( $2 b)$, it is the activity of sleeping. 


\section{Predicate formation}

One of the crucial ingredients in relative clause formation is the formation of a predicate, which can then predicate of a head noun. As mentioned above, Mandarin relative clauses are all 'marked' by the presence of $d e .^{3} \mathrm{In}$ Aoun and Li (2003), three separate strategies are proposed for relativization in Chinese, all of which involve an adjunction structure (not a complement structure). The first strategy takes care of typical arguments; it involves raising of an NP to form a predicate. The second strategy concerns adjuncts of the type we have seen in (3) and this strategy involves empty operator movement and a base-generated head noun. Aoun and Li remain vague about how the aboutness relatives of the type in (2) come about in their structural representations/derivations (A\&L, ex. (73), p. 190).

What the different types of relatives share is that there is a clausal predicate which modifies a head noun. In other words, at some level, there is a predication relation between the relative clause and the head noun. The question that we as well as Van Riemsdijk $(1989,2003)$ are intrigued by is how this predication relation comes about in the case of aboutness relatives. As we saw, in the argumental and adjunct relatives, there is an uncontroversial gap in the clause, associated with an operator. The operator-variable pair can be interpreted semantically as predicate abstraction, which then relates to the head noun. The problem with the apparently gapless aboutness variety in (2) is how the predicate abstraction comes about, or syntactically, how an operator-variable pair can be created. As we just saw, Van Riemsdijk (2003) proposes an expletive adjunct operator to account for the aboutness semantics in a regular syntactic way.

However, despite of the fact that Züritüüsch and Mandarin relatives have invariant relative markers ( $w o$ and de respectively), the expletive adjunct analysis cannot be easily accomodated in Mandarin. In particular, the restrictions on activity verbs as well as generic activity reading of gapless relatives in Mandarin seem problematic to such an analysis. Below we propose an analysis of the Mandarin aboutness relatives and conclude that they are gapless after all.

\subsection{De and predication}

As noted above, de is a general modification marker, which appears with all prenominal modifiers, such as adjectival modifiers, possessors and

\footnotetext{
3 This is actually not entirely true. There are cases in which de is optional. For instance, de is optional when the relative clause precedes the demonstrative.
} 
relative clauses. It also shows up in clefts. In other words, its presence signals predication. It can be considered a generalized $\lambda$-abstraction operator (cf. Butler 2004). ${ }^{4}$ The operator can bind either an argument variable (leading to an argumental relative clause), or an adjunct variable (yielding an adjunct relative clause). ${ }^{5}$ And, what is more important to the present discussion, we propose that this operator can also bind an event variable, which is exactly what happens in the apparent gapless aboutness relatives of the kind in (2).

We have seen above that the relatives concerned require an activity verb. This strongly suggests that the event variable plays a crucial role in the account of these sentences. We also saw that these relatives have a generic activity reading. The activity requirement and the generic reading add up as follows. Normally an event variable is bound by some temporal operator (or by existential closure) linking the event to some spatialtemporal location. Consider the example in (8).

(8) a. tā chàng-guo zhè-shŏu ge $\overline{\mathrm{e}}$

he sing-EXP this-CL song

'He sang this song before.'

b. $g u o=$ past event operator; $\mathrm{V}\left(\mathrm{a}_{1}, \mathrm{a}_{2}, \mathrm{e}\right)$

What (8) illustrates is that the event variable (indicated by $e$ in (8b)) of the verb chàng 'sing' can be bound by the aspectual operator guo, yielding the reading indicated in (8a). Consider now (2a) and (7c), repeated below.

(2) a. [tā chàng gē de] shēngyīn he sing song DE voice

'the voice that he has while singing'

(7)
c. * [tā chàng-guo (nèi-shŏu) gē
de] shēngyīn
he sing-EXP that-CL song DE voice

Intended: 'the voice that he had when he sang (the) song before.'

\footnotetext{
${ }^{4}$ This can be implemented syntactically along the lines of Adger and Ramchand (2005) with de hosting a feature $[\Lambda]$ which is interpreted as predicate abstraction.

${ }^{5}$ This goes counter the conclusion in Aoun and Li (2003) for both argument and adjunct relatives, since the current proposal entails base-generation in all relatives in Chinese. Aoun and Li (2003) pointed out that neither reconstruction, nor island effects are consistent in Chinese. Given the analysis suggested here, further work needs to be done to see whether the analysis for aboutness relatives proposed here can be extended to all relatives.
} 
In (2a), de, the generalized abstraction operator, can bind the event variable, creating a predicate which can predicate of the head noun shēngyin' 'voice, sound'. This predicate only expresses a generic reading of the activity because the event of singing is not temporally bound by a temporal operator. In the ungrammatical $(7 \mathrm{c})$, the event variable is already bound by the aspectual guo, making it impossible for de to bind it. This means that relatives without an argumental or adjunct variable cannot have a predicate without an event variable or with an event variable that is already bound by another operator.

The predicate generated by de binding an event operator will yield a generic event reading. The phrase in (2a) can thus be interpreted as the voice with the property of his singing.

\section{Conclusion}

We have shown that Mandarin relatives of the kind in $(2 a, b)$ are gapless after all. The reason why a gapless relative can exist is due to the combination of having a generalized $\lambda$-abstraction operator (de) and an event variable. This limits the range of possible gapless/aboutness relatives to relatives with a generic activity reading.

The analysis we proposed here for gapless relatives entails that the head noun is base-generated external to the relative clause, and that there is no empty operator movement within the relative (cf. Adger and Ramchand's 2005 analysis of Scottish Gaelic). Whether this analysis can be extended to all relatives in Mandarin needs to be further investigated. Perhaps this analysis can even be extended to the Züritüitsch relatives discussed in Van Riemsdijk 2003. In any case, the cases in which wo is supposed to be associated with an expletive adjunct given in that paper all seem to involve a kind of generic activity reading as well.

\section{References}

Adger, David, and Gillian Ramchand. 2005. Merge and Move: Wh-Dependencies Revisited. Linguistic Inquiry 36:161-193.

Aoun, Joseph, and Yen-hui Audrey Li. 2003. Esseays on the representational and derivational nature of grammar: The diversity of $W h$-constructions. Cambridge: MIT Press.

Butler, Jonny. 2004. On having arguments and agreeing: semantic EPP. York Papers in Linguistics series 2:1-27.

Cheng, Lisa L.-S. 1997. On possession in Cantonese, Mandarin and Taiwanese, Paper presented at ICCL 6, University of Leiden. 
Dikken, Marcel den, and Pronsiri Singhapreecha. 2004. Complex Noun Phrases and Linkers. Syntax 7:1-54.

Ning, Chunyan. 1993. The overt syntax of relativization and topicalization in Chinese, University of California, Irvine: PhD Dissertation.

Riemsdijk, Henk C. van. 2003. East meets West. In Germania et Alia, a linguistic webschrift for Hans den Besten, eds. Jan Kosten and Henk C. van Riemsdijk. odur.let.rug.nl/ koster/DenBesten/contents.htm.

Riemsdijk, Henk C. van. 1989. Swiss Relatives. In Sentential complementation and the lexicon. Studies in Honor of Wim De Geest, eds. Dany Jaspers, Wim Klooster, Yvan Putseys and Pieter Seuren. Dordrecht: Foris.

Paul, Waltraud. 2003. Adjectival modification in Mandarin Chinese and related issues. Ms. 